\title{
中心静脈確保：大腿静脈アプローチの功罪
}

超音波ガイド下に末梢側大腿静脈に中心静脈カテー テルを挿入するという徳嶺ら1の方法は, 彼らも述べ ているように, Satoら 2)がAnesthesiology 誌に1998年 に報告したものであり，その後も木原らによる多数例 の報告 ${ }^{3), 4)}$ があり，手技的に特に目新しいものではな い。今回は, 通常の大腿静脈穿刺部位に潰瘍形成, 内 颈静脈, 鎖骨下静脈穿刺部位に広範な皮下気腫があり, 「選択の余地がなかったため」, この方法が施行されて いる。木原ら ${ }^{4)}$ は29名の患者に対しこの方法を意図 的に行なっているが, その理由として, 鼠径部が会陰 部に近いことから不潔になりやすいこと, 穿刺部位が 関節可動部にあたるため固定やドレーピングが難しい ことを挙げている。

挿入部位別の中心静脈カテーテル挿入に伴う感染の 可能性に関して, 無作為試験で大腿静脈穿刺は鎖骨下 静脈穿刺と比べて全体で 5 6倍, 臨床的な敗血症に関 しては 3 倍近くの頻度で発生すると報告されている5)。 また無作為試験ではないが, 鎖骨下静脈穿刺は内頝静 脈穿刺よりも感染率が低いとされている6)。このよう に大腿静脈穿刺は感染に関して不利であるが，末梢側 大腿静脈からの穿刺とすると, 通常部位での穿刺に比 べて感染率が低下することが予想される。しかし, 残 念ながらこれに関するデータはない。

大腿静脈を穿刺部位とすることの不利は血栓症発生 においてさらに大きく, 鎖骨下静脈の 10 倍以上との報 告5)がある。徳嶺らの報告1)では血栓形成について触 れておらず, 残念である。より末梢側からの穿刺では, 血管径が細いため, より血栓が形成されやすいとも想 像されるが, これも同様にデー夕はない。木原ら3)は 末梢側大腿静脈穿刺の短所として, 筋層を貫いてカ テーテルを挿入するため術後筋肉痛が生じやすいこと や，時間を経て血腫を形成する場合に発見されにくい 可能性を挙げているが, 徳嶺らの症例ではそのような ことはなかったとしている。

徳嶺ら ${ }^{1)}$ は, 大腿静脈からの穿刺では穿刺時の機械 的合併症が少ないとしているが, 他の古謝・徳嶺らの 論文7)のデー夕からは必ずしもそのようには読み取れ

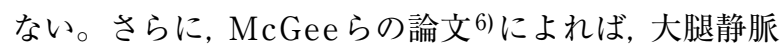
穿刺は鎖骨下静脈穿刺, 内頚静脈穿刺に比べて, 全体
としては機械的合併症の発生率は最も高い。血胸, 気 胸の合併症は当然ながら無いが, 動脈誤穿刺, 血腫形 成の合併症発生率がより高いためである。

以上, 大腿静脈からの穿刺は不利な点が多いが, 蘇生 現場ではこの方法が有利である。胸骨圧迫心マッサー ジ，抻管などの手技を比較的妨げることなく迅速にカ テーテルを挿入することができるためである。ただし， 蘇生が一段落した後には, 早めに内頝静脈または鎖骨 下静脈からの穿刺に変更することが推奨される6)。

さて, 通常の大腿静脈穿刺の機械的合併症として, 徳嶺らの報告に関連して, 大腿動脈誤穿刺に言及しょ う。鼠径部における大腿動静脈の位置関係を超音波で 観察した報告では, 動脈は静脈より表層に位置し, 動 静脈が完全に重ならない確率は, 鼠径勒帯レベルで右 $72 \%$, 左 $59 \%$, 鼠径勒带より $2 \mathrm{~cm}$ 末梢で右 $26 \%$, 左 $31 \%$, 鼠径勒帯より $4 \mathrm{~cm}$ 末梢で右 $0 \%$, 左 $2 \%$ とされ ている8)。動脈誤穿刺の観点からは, できるだけ鼠径 勒帯に近く,できれば右の大腿静脈から行なうべきで あろう。ただし, 右大腿静脈は鼠径勒帯より中枢側で 右外腸骨静脈となるが, 右外腸骨動脈と交差するため, 右鼠径勒帯近くで鋭角に深く刺入すると右外腸骨動脈 を穿刺し, 圧迫止血困難な出血や後腹膜血腫を生じる 可能性がある7)。このため多くの教科書では, 鼠径勒 帯の $1-2$ 横指末梢側での穿刺を薦めている。

ここで, 鼠径勒帯の位置同定について, 触診ではし ばしば困難であること ${ }^{9}$, 特に肥満者では, 鼠径勒帯 の位置はいわゆる鼠径部の「しわ」と同位置ではない ことに留意されたい。鼠径勒带は聎骨結合と上前腸 骨棘を結ぶ線で想定すべきである。この点を強調す る理由は以下の点にある。総大腿動脈は鼠径勒帯より 末梢平均 $3 \mathrm{~cm}(1 \sim 5 \mathrm{~cm})$ で大腿深動脈を分岐する ${ }^{8)}$ 。 鼠径勒帯よりかなり末梢側で動脈誤穿刺を行なった 場合, 浅大腿動脈だけでなく大腿深動脈をも穿刺する と, 血腫に気づかないことがある。また, 中心静脈力 テーテル挿入とは異なるが, 鼠径勒帯末梢側に留意す るあまり, percutaneous cardiopulmonary support (PCPS) の送血管扦入を総大腿動脈でなく, やや細径 の浅大腿動脈から行なった場合は, 下肢虚血の危険性 が増すかもしれない。 
大腿静脈穿刺の機械的合併症には, 徳嶺ら1)も指摘 するとおうり, 後腹膜血腫 ${ }^{10)}$, 動静脈瘦 ${ }^{11), 12)}$, 腸腰筋膿 瘍 13$)$, 腹胿内への誤留置 ${ }^{14)}$ などの報告があるが, 誤留 置については, 腎静脈, 肝静脈, 対側の腸骨静脈に加 えて, 上行腰静脈への誤留置にも注意されたい。これ は単純X線写真では判別がときに困難で, 診断にCT を必要とすることがある。細い上行腰静脈に留置した カテーテルからの高カロリー輸液によって, 血管炎か ら腸腰筋膿瘍に至ることがある15)。他の合併症とし て, 大腿神経麻痺 ${ }^{16)}$, 閉鎖動脈の分枝である死冠の損 傷 17$)$ な゙の報告もある。

次に, 徳嶺論文の主要な論点である超音波ガイド下 中心静脈穿刺について言及する。超音波ガイド下穿刺 では, リアルタイムに穿刺針を血管内に挿入し，ガイ ドワイヤーの確認もできる。内䅡静脈穿刺での超音波 ガイド下穿刺は, 機械的合併症・誤留置・挿入時間を 減少させること ${ }^{18), 19)}$, 初心者の成功率が高いこと20) が報告されている。超音波ガイド下中心静脈穿刺は今 後, 中心静脈穿刺の標準的方法として定着する可能性 が高く, 合併症を急速に低下させるために早急な普及 が望まれる。

超音波ガイド下穿刺を安全に施行できる標準的方法 を定着させるためには, 血管穿刺の器材についても, さらに改良すべき課題がある。

第一は, 穿刺針に関して, 金属針を使うか, 静脈留 置針を使うか, さらには針の太さに関してである。金 属針は, 超音波にて血管内に位置を確認できればその ままガイドワイヤーを送り込める利点があるが, 針の 固定に慣れが必要である。静脈留置針では, 外套留置, 内套抜去の間に外套の先の位置がずれることがある。 次に, 針の太さに関しては, 太い針ほど進めるときに 静脈前壁が圧迫され，内腔がつぶれやすくなる。穿刺 時に静脈の血管径をできるだけ保持しながら静脈前壁 のみを貫ける針を使えば，超音波ガイド下の利点が大 きくなると思われる。この観点から, 鈴木 ${ }^{21)}$ は 22 ゲー ジ金属針にガイドワイヤー挿入用の側孔を作り， 0.018インチの細いガイドワイヤーを金属針の内望を 通じて挿入できる穿刺針を開発している。

第二は, ガイドワイヤーに関してである。上記金属 針を用いる方法では, ガイドワイヤーに関したトラブ ルとして，ロッキング現象や断裂が危惧される。西脇 ら 22) はこの点に鑑み, ガイドワイヤー挿入に金属針を 用いないことを推奨している。鈴木 ${ }^{21)}$ は, 金属針でも 使えるようにガイドワイヤーの構造の改良を行なって いるが, 今後の報告を待ちたい。

超音波ガイド下穿刺の具体的方法については, リア
ルタイムに穿刺せず，超音波ガイド下に穿刺部位に印 をつけた後に穿刺する場合もあるが, landmark technique との比較で合併症の発生率に差がないとの報告 ${ }^{23)}$ もある。さらに, 穿刺針の動かし方 ${ }^{4}$, 描出が比較的 難しいとされる鎖骨下静脈からの穿刺法6), 新生児,

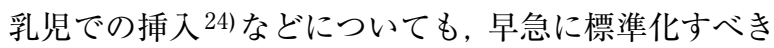
課題は多いと考えられる。

大腿静脈穿刺に限らず, 中心静脈穿刺, カテーテル 挿入に関しては，さらに(1)適応の厳密化，(2)教育体制 の充実とインストラクター制度の導入 25$)$, (3)サーベイ ランス, (4)超音波ガイド下穿刺の更なる普及など, 整 備しなければならない問題は目白押しである。

以上, 大腿静脈からの中心静脈カテーテル扱入に関 連して, すでに各所に記載されている教科書的な解説 を省き，今日的な課題に絞って論じた。

\section{貝沼 関志}

藤田保健衛生大学医学部麻醉学 (Surgical ICU)

（テ470-1192 愛知県豊明市沓掛町田楽が寉 1-98）

Central venous catheterization: controversy about femoral venous approach

Key words: (1) central venous catheterization, (2) femoral vein, (3) ultrasound guidance

Motoshi Kainuma

Division of Surgical Intensive Care, Department of Anesthesiology, Fujita Health University

1-98 Dengakugakubo, Kutsukake-cho, Toyoake, Aichi 470-1192, Japan

J Jpn Soc Intensive Care Med. 2008;15:11 13.

\section{文 献}

1) 徳嶺譲芳，新田憲市，照屋孝二，他．超音波ガイド下に末 梢側大腿静脈ラインを確保した一例。日集中医誌. 2008; 15:79-81.

2) Sato S, Ueno E, Toyooka H. Central venous access via the distal femoral vein using ultrasound guidance. Anesthesiology. 1998;88:838-9.

3) 木原真一, 佐藤重仁, 猪股伸一, 他. 大腿部からのエコー ガイド下穿刺中心静脈カテーテル留置が有用であった 2 症 例. 麻酔. 1998;47:1253-6.

4）木原真一, 佐藤重仁, 宮部雅幸, 他. エコーガイド下大腿 静脈穿刺による中心静脈カテーテル留置法の検討。日臨麻 会誌. 1999;19:36-41.

5) Merrer J, De Jonghe B, Golliot E, et al. Complications of femoral and subclavian venous catheterization in critically ill patients: a randomized controlled trial. JAMA. 2001; 286:700-7.

6) McGee DC, Gould MK. Preventing complications of 
central venous catheterization. N Engl J Med. 2003;348: 1123-33.

7) 古謝宏樹, 徳嶺譲芳, 須加原一博. 中心静脈穿刺の機械的 合併症．麻酔．2007;56:48-56.

8) Hughes P, Scott C, Bodenham A. Ultrasonography of the femoral vessels in the groin: implications for vascular access. Anaesthesia. 2000;55:1198-202.

9) Rupp SB, Vogelzang RL, Nemcek AA Jr, et al. Relationship of the inguinal ligament to pelvic radiographic landmarks: anatomic correlation and its role in femoral arteriography. J Vasc Interv Radiol. 1993;4: 409-13.

10) Akata T, Nakayama T, Kandabashi $T$, et al. Massive retroperitoneal hemorrhage associated with femoral vein cannulation. J Clin Anesth. 1998;10:321-6.

11) Agresti JV, Schwartz AB, Chinitz JL, et al. Delayed traumatic atriovenous fistula following hemodialysis catheterization. Nephron. 1987;46:350-2.

12) Kuramochi G, Ohara N, Hasegawa S, et al. Femoral arterioveous fistula: a complication of temporary hemodialysis catheter placement. J Artif Organs. 2006;9:114-7.

13) Kikuchi S, Muro K, Yoh K, et al. Two cases of psoas abscess with discitis by methicillin-resisitant Staphylococcus aureus as a complication of femoral-vein catheterization for haemodialysis. Nephrol Dial Transplant. 1999;14: 1279-81.

14) Celiker V, Akinci SB, Basgul E, et al. Misplacement of femoral catheter into the abdominal cavity. Acta Anaesthesiol Scand. 2004;48:258

15）貝沼関志．大腿静脈からの穿刺法． Lisa. 2006;13:1118-21.
16) Ho KM, Lim HH. Femoral nerve palsy: an usual complication after femoral nerve puncture in a patient with severe coagulopathy. Anesth Analg. 1999;89:672-3.

17) 清水 聡, 広間文彦, 相馬祐人, 他. 中心静脈カテーテル により死冠損傷を併発した1例. 日臨救医誌. 2003;6:412-5.

18) Teichgraber UK, Benter T, Gebel M, et al. A sonographically guided technique for central venous access. AJR Am J Roentgenol. 1997;169:731-3.

19) Randolph AG, Cook DJ, Gonzales CA, et al. Ultrasound guidance for placement of central venous catheters: a meta-analysis of the literature. Crit Care Med. 1996;24: 2053-8.

20) Gualtieri F, Deppe SA, Sipperly ME, et al. Subclavian venous catheterization: greater success rate for less experienced operators using ultrasound guidance. Crit Care Med. 1995;23:692-7.

21) 鈴木利保. 穿刺器材からみた血管穿刺の安全性. Lisa. 2006;13:1094-100.

22) 西脇公俊, 佐藤栄一. 穿刺 - 扱入操作, 扦入後の処置. Lisa. 2006;13:1006-11.

23) Mansfield PF, Hohn DC, Fornage BD, et al. Complications and failures of subclavian-vein catheterization. N Engl J Med. 1994:331:1735-8.

24) 黒部明子, 堀本 洋. 新生児, 乳児の内頸静脈カテーテル 挿入 (multi-lumen). 貝沼関志編. 麻酔・救急・集中治療 専門医のわざ．東京：真興交易医書出版部；2000. p. 47-9.

25) 松本昌平, 三木 保. 中心静脈穿刺の教育体制. Lisa. 2006;13:1.

受付日 2007 年 7 月 2 日 採択日 2007 年 8 月 20 日

\section{脳梗塞超急性期症例における early CT signs と局所線溶療法}

脳梗塞超急性期症例に対する線溶療法は, 現在最も 関心が高い話題である。2005年10月に組織プラスミ ノーゲンアクチベーター (tissue plasminogen activator, t-PA）（アルテプラーゼ）の静注療法が本邦でも認 可されて以来, 年間に 4,000 例程度の施行例がある。 本号で報告された症例1)をまとめてみると, 左不全麻 瘏で発症し, 発症 1 時間後のCTで右中大脳動脈領域 に広範な early CT signを認め, 発症 1.5 時間後の MRI ではCT と同じ領域に拡散強調画像で高信号域を認め た。発症 2 時後に脳血管撮影を施行し, 右 $\mathrm{M} 2$ 閉塞を 認めたが, 局所線溶療法 (ウロキナーゼ 6 万単位 $\times 3$ ) により完全再開通が認められ, 臨床症状は著明に改善 した。2日後の MRI T2では右前頭葉皮質と右島皮質
に高信号を認めている。

\section{ガイドライン・大規模臨床試験における 局所線溶療法と early CT sign}

「脳卒中治療ガイドライン 2004」2)において, 局所線 溶療法は「神経脱落症状を有する中大脳動脈塞栓性梗 塞で, 来院時の症状が軽症から中等症で, $\mathrm{CT}$ 上梗塞巣 を認めず, 発症から 6 時間以内に治療開始が可能な症 例」に対し適応が推奨されている (グレードB)。発症 6 時間以内の中大脳動脈梗塞患者に対する recombinant prourokinase (r-proUK) による局所線溶療法の 有效性の検討を行ったProlyse in Acute Cerebral Thromboembolism II (PROACT II ) 3)では, CT の除 